Section Editor

Mitchell S.V. Elkind, MD, MS

\section{Teaching NeuroImages: Headache with pulsatile tinnitus}

R.J.E. Armstrong, $\mathrm{PhD}$, MRCP

J. Downer, FRCR

N. Evans, MB BChir

P. Anslow, FRCR

G.C. Ebers, MD,

FMedSci

Address correspondence and reprint requests to Dr. R.J.E. Armstrong, Department of Clinical Neurology, Level 3, West Wing, John Radcliffe Hospital, University of Oxford, Headley Way, Oxford OX3 9DU, UK richard.armstrong@clneuro.ox.ac.uk

Figure Imaging

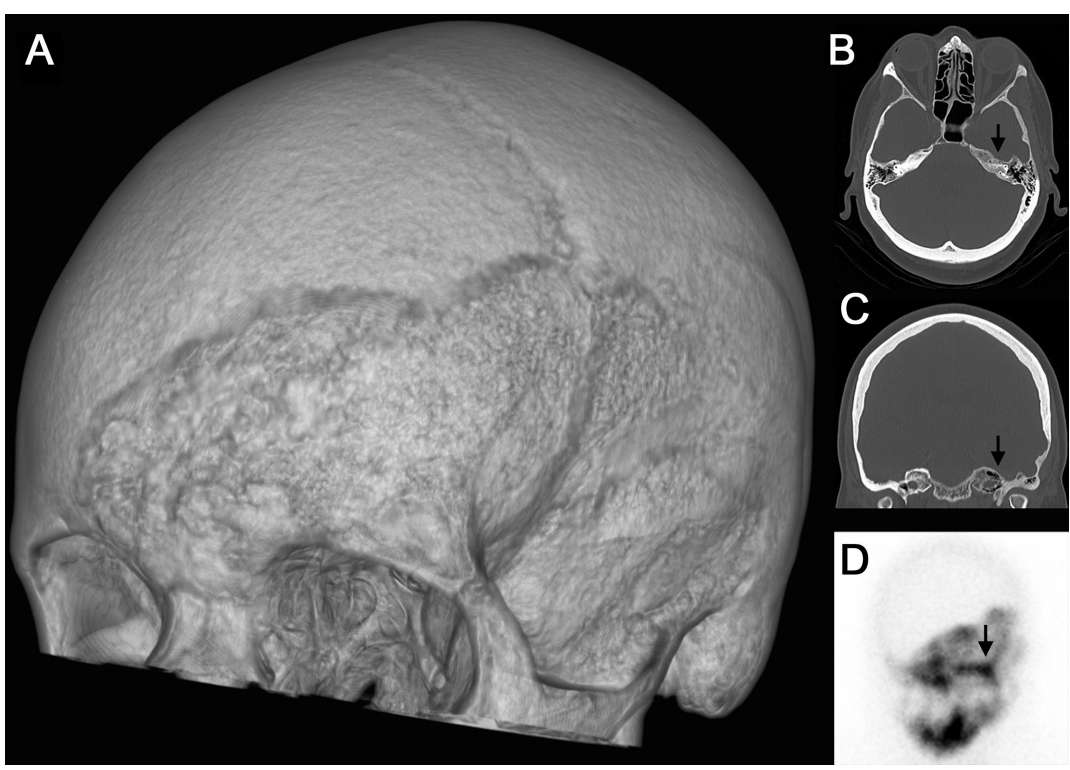

CT reconstructions dramatically show an advancing osteoclastic front of bone resorption involving left frontal, parietal, and temporal bones in the acute, lytic phase of Paget disease (A). Cross-sectional images show extension into the petrous bone (indicated) and skull base (B, C). Tc99m-bone scintigraphy confirms increased uptake in these areas (D).

A 62-year-old woman presented with 3 months of insidious-onset, persistent headache focused around the left temple. She had left-sided pulsatile tinnitus and the affected area was warm to touch. Neurologic examination, including hearing, was normal with no objective bruit. A minimally elevated alkaline phosphatase (282 U/L) was the only blood abnormality. Imaging (figure) revealed osteoporosis circumscripta: the acute lytic phase of Paget disease. Although frequently asymptomatic, associated bone pain may present as headache. The vascularity of the petrous lesion explains the tinnitus. Treatment with antiresorptive agents modestly improved the headache and may prevent ensuant neurologic complications attributed to the proliferative phase. ${ }^{1}$

\section{DISCLOSURE}

Dr. Armstrong reports no disclosures. Dr. Downer has received funding for travel from eV3 Neurovascular Inc. Dr. Anslow receives publishing royalties for Neurological Case Histories (Oxford University Press, 2007). Dr. Evans reports no disclosures. Dr. Ebers serves on the editorial boards of the International Multiple Sclerosis Journal and Multiple Sclerosis and as Section Editor for BMC Medical Genetics; has received funding for travel or speaker honoraria from Bayer Schering Pharma, sanofi-aventis, Roche, and UCB; has served as a consultant to Biopartners, Bayer Schering Pharma, Howrey LLP, Heron Health, and Eli Lilly and Company; and receives research support from Bayer Schering Pharma, the Multiple Sclerosis Society of the United Kingdom, and the Multiple Sclerosis Society of Canada Scientific Research Foundation.

\section{REFERENCE}

1. Ralston SH, Langston AL, Reid IR. Pathogenesis and management of Paget's disease of bone. Lancet 2008;372: 155-163. 


\section{Neurology}

\section{Teaching NeuroImages: Headache with pulsatile tinnitus}

R.J.E. Armstrong, J. Downer, N. Evans, et al.

Neurology 2011;76; 82

DOI 10.1212/WNL.0b013e3182181067

\section{This information is current as of April 25, 2011}

Updated Information \& Services

References

Subspecialty Collections

Permissions \& Licensing

Reprints including high resolution figures, can be found at: http://n.neurology.org/content/76/17/e82.full

This article cites 1 articles, 0 of which you can access for free at: http://n.neurology.org/content/76/17/e82.full\#ref-list-1

This article, along with others on similar topics, appears in the following collection(s):

\section{All Medical/Systemic disease}

http://n.neurology.org/cgi/collection/all_medical_systemic_disease CT

http://n.neurology.org/cgi/collection/ct

Secondary headache disorders

http://n.neurology.org/cgi/collection/secondary_headache_disorders

Information about reproducing this article in parts (figures,tables) or in its entirety can be found online at:

http://www.neurology.org/about/about_the_journal\#permissions

Information about ordering reprints can be found online:

http://n.neurology.org/subscribers/advertise

Neurology ${ }^{\circledR}$ is the official journal of the American Academy of Neurology. Published continuously since 1951, it is now a weekly with 48 issues per year. Copyright Copyright $@ 2011$ by AAN Enterprises, Inc.. All rights reserved. Print ISSN: 0028-3878. Online ISSN: 1526-632X.

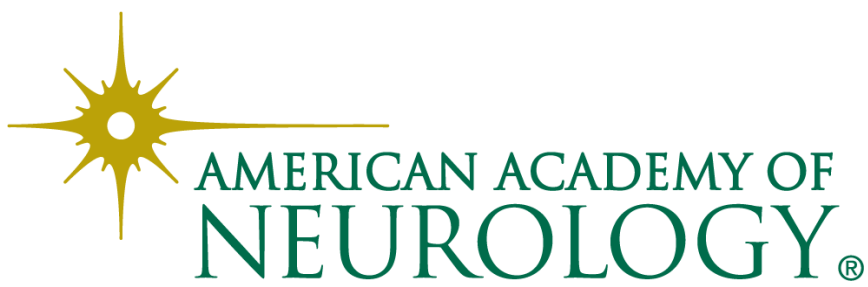

